\title{
KOMUNIKASI YANG EFEKTIF
}

\author{
DWI FEBRIANA \\ 175100003 \\ Universitas Mitra Indonesia, Sistem Informasi \\ dwifebriana.student@umitra.ac.id
}

\begin{abstract}
ABSTRAK
Komunikasi tidak terbatas pada kata-kata yang terucap belaka, melainkan bentuk dari apa saja interaksi, senyuman, anggukan kepala yang membenarkan hati, sikap badan, ungkapan minat, sikap dan perasaan yang sama. Diterimanya pengertian yang sama adalah merupakan kunci dalam komunikasi. Tanpa penerimaan sesuatu dengan pengertian yang sama, maka yang terjadi adalah "dialog antara orang satu".
\end{abstract}

Kata Kunci : Komunikasi 


\section{A. PENDAHULUAN}

Komunikasi merupakan aktifitas manusia yang sangat penting. Bukan hanya dalam kehidupan organisasi, namun dalam kehidupan manusia secara umum. Komunikasi merupakan hal yang esensial dalam kehidupan kita. Kita semua berinteraksi dengan sesama dengan cara melakukan komunikasi. Komunikasi dapat dilakukan dengan cara yang sederhana sampai yang kompleks, dan teknologi kini telah merubah cara

manusia berkomunikasi secara drastis.

Komunikasi tidak terbatas pada kata-kata yang terucap belaka, melainkan bentuk dari apa saja interaksi, senyuman, anggukan kepala yang membenarkan hati, sikap badan, ungkapan minat, sikap dan perasaan yang sama. Diterimanya pengertian yang sama adalah merupakan kunci dalam komunikasi. Tanpa penerimaan sesuatu dengan pengertian yang sama, maka yang terjadi adalah "dialog antara orang satu”.

Organisasi

atau Organization bersumber dari kata kerja bahasa latin Organizare"to form as or into a whole consisting of interdependent or coordinated parts (membentuk sebagai atau menjadi keseluruhan dari bagian-bagian yang saling bergantung atau terkoordinasi). Organisasi adalah sarana dimana manajemen mengkoordinasikan sumber bahan dan sumber daya manusia melalui pola struktur formal dari tugas-tugas dan wewenang.

Tujuan organisasi tidak akan tercapai apabila tanpa manajemen dan komunikasi. Manajemen tidak akan mungkin ada tanpa organisasi. Manajemen ada, jika ada tujuan yang akan dicapai dan diselesaikan. Korelasi antara ilmu komunikasi dengan organisasi terletak pada peninjauannya yang terfokus pada manusia-manusia yng terlibat dalam mencapai tujuan organisasi.

Tujuan organisasi juga tidak terlepas dari peran pemimpin. 
Pemimpin yang baik adalah pemimpin yang mampu menguasai komunikasi dengan baik pula. Dengan penguasaan komunikasi yang baik seorang pemimpin memiliki nilai tambah, baik dalam kehidupannya secara umum, maupun dalam mengkontribusikan dirinya di tempat kerja, sehingga lebih produktif.

Komunikasi juga dikatakan sebagai inti dari kepemimpinan. Kepemimpinan yang efektif dapat dicapai melalui proses komunikasi yang dilakukan oleh pemimpin kepada anggotanya. Visi pemimpin bisa saja bagus, namun tanpa komunikasi yang efektif, maka visi tersebut tidak akan pernah bisa terwujud. Dalam mengkomunikasikan visi, maka pemimpin harus bisa menyampaikan suatu gambaran di masa depan yang mendorong antusiasme serta komitmen orang lain.

\section{B. TINJAUAN PUSTAKA}

Komunikasi (communicare, latin) artinya berbicara atau menyampaikan pesan, informasi, pikiran, perasaan yang dilakukan seseorang kepada yang lain dengan mengharapkan jawaban, tanggapan, dari orang lain (Hohenberg : 1978).

\section{C.STUDY KASUS}

A. Pengertian Komunikasi

Istilah komunikasi berasal dari kata Latin Communicare atau Communis yang berartisamaataumenjadikan milik bersama. Kalau kita berkomunikasi dengan orang lain, berartikita berusaha agarapa yang disampaikan kepada orang lain tersebut menjadi miliknya.

Beberapa definisi komunikasi adalah:

Komunikasi adalah kegiatan pengoperan lambang yang mengandung arti/makna yang perlu dipahami bersama oleh pihak yang terlibat dalam kegiatan komunikasi(Astrid).

Komunikasi adalah sebagai pemindahan informasi dan pengertian 
dari satu orang ke orang lain (Davis, 1981).

Komunikasi adalah berusaha untuk mengadakan persamaan dengan orang lain (Schram,W)

Komunikasi adalah penyampaian dan memahami pesan dari satu orang kepada orang lain, komunikasi merupakan proses sosial (Modul PRT, Lembaga Administrasi).

Komunikasi bermula dari sebuah gagasan yang ada pada diri seseorang yang diolah menjadi sebuah pesan dan disampaikan atau dikirimkan kepada orang lain dengan menggunakan media tertentu. Dari pesan yang disampaikan tersebut kemudian terdapat timbale balik berupa tanggapan atau jawaban dari orang yang menerima pesan tersebut. Dari proses terjadinya komunikasi itu, secara teknis pelaksanaan, komunikasi dapat dirumuskan sebagai kegiatan dimana seseorang menyampaikan pesan melalui media tertentu kepada orang lain dan sesudah menerima pesan serta memahami sejauh kemampuannya, penerima pesan menyampaikan tanggapan melalui media tertentu pula kepada orang yang menyampaikan pesan itu kepadanya (Agus M. Hardjana :Komunikasi intrapersonal dan interpersonal, 2003).

Komunikasi organisasi adalah pengiriman dan penerimaan berbagai pesan organisasi di dalam kelompok formal maupun informal dari suatu organisasi (Wiryanto, 2005). Komunikasi formal adalah komunikasi yang disetujui oleh organisasi itu sendiri dan sifatnya berorientasi kepentingan organisasi. Isinya berupa cara kerja di dalam organisasi, produktivitas, dan berbagai pekerjaan yang harus dilakukan dalam organisasi. Misalnya: memo, kebijakan, pernyataan, jumpa pers, dan surat-surat resmi. Adapun komunikasi informal adalah komunikasi yang disetujui secara sosial. Orientasinya bukan pada organisasi, tetapi lebih kepada anggotanya secara individual.

B. Proses Komunikasi

Proses komunikasi adalah 
bagaimana sang komunikator menyampaikan pesan kepada komunikannya, sehingga dapat dapat menciptakan suatu persamaan makna antara komunikan dengan komunikatornya. Proses Komunikasi ini bertujuan untuk menciptakan komunikasi yag efektif (sesuai dengan tujuan komunikasi pada umumnya).

Proses Komunikasi, banyak melalui perkembangan. Pada penjelasan ini, akan dijelaskan berbagai proses komunikasi melalui model-model komunikasi itu sendiri :

1. Model Komunikasi Aristoteles

$$
\text { Aristoteles menerangkan }
$$

tentang model komunikasi dalam bukunya Rhetorica, bahwa setiap komunikasi akan berjalan jika terdapat 3 unsur utama :

Pembicara, yaitu orang yang menyampaikan pesan

Apa yang akan dibicarakan (menyangkut Pesan nya itu sendiri)

Penerima, orang yang menerima pesan tersebut.
2. Model Komunikasi David K.Berlo

Dalam model komunikasi David K.Berlo, diketahui bahwa komunikasi terdiri dari 4 Proses Utama yaitu SMRC (Source, Message, Channel, dan Receiver) lalu ditambah 3 Proses sekunder, yaitu Feedback, Efek, dan Lingkungan.

Source (Sumber), Sumber adalah seseorang yang memberikan pesan atau dalam komunikasi dapat disebut sebagai komunikator. Walaupun sumber biasanya melibatkan individu, namun dalam hal ini sumberjuga melibatkan banyak individu. Misalnya, dalam organisasi, Partai, atau lembaga tertentu. Sumber juga sering dikatakan sebagai source, sender, atau encoder.

Message (Pesan), pesan adalah isi dari komunikasi yang memiliki nilai dan disampaikan oleh seseorang (komunikator). Pesan bersifat menghibur, informatif, edukatif, persuasif, dan juga bisa bersifat propaganda. Pesan disampaikan melalui 2 cara, yaitu Verbal dan Nonverbal. Bisa melalui 
tatap muka atau melalui sebuah media komunikasi. Pesan bisa dikatakan sebagai Message, Content, atau Information

Channel (Media dan saluran komunikasi), Sebuah saluran komunikasi terdiri atas 3 bagian. Lisan, Tertulis, dan Elektronik. Media disini adalah sebuah alat untuk mengirimkan pesan tersebut. Misal secara personal (komunikasi interpersonal), maka media komunikasi yang digunakan adalah panca indra atau bisa memakai media telepon, telegram, handphone, yang bersifat pribadi. Sedangkan komunikasi yang bersifat massa (komunikasi massa), dapat menggunakan media cetak (koran, suratkabar, majalah, dll) , dan media elektornik(TV, Radio). Untuk Internet, termasuk media yang fleksibel, karena bisa bersifat pribadi dan bisa bersifat massa. Karena, internet mencakup segalanya. Jika anda membuka www.kuliahkomunikasi.com < maka media ini bersifat massal, namun jika anda chattingh melalui yahoo messenger, maka media ini bersifat interpersonal, dan jika anda menuliskan Blog (blogging atau menulis diary), media ini bisa berubah menjadi media yang bersifat Intrapersonal (kepada diri sendiri).

Receiver (Penerima Pesan), Penerima adalah orang yang mendapatkan pesan dari komunikator melalui media. Penerima adalah elemen yang penting dalam menjalankan sebuah proses komunikasi. Karena, penerima menjadi sasaran dari komunikasi tersebut. Penerima dapat juga disebut sebagai public, khalayak, masyarakat, dII.

Elemen Tambahan :

Feedback (Umpan Balik), Umpan balik adalah suatu respon yang diberikan oleh penerima. Penerima disini bukan dimaksudkan kepada penerima sasaran (khalayak), namun juga bisa didapatkan dari media itu sendiri. Misal, kita sebagai seorang penulis mengirimkan sebuah artikel kepada suatu media massa. Lalu, bisa saja kita artikel kita ternyata 
bagus, namun ada beberapa hal yang harus di edit. Sehingga, pihak media mengembalikan artikel kita untuk di edit ulang.

Efek, sebuah komunikasi dapat menyebabkan efek tertentu. Efek komunikasi adalah sebuah respon pada diri sendiri yang bisa dirasakan ketika kita mengalami perubahan (baik itu negatif atau positif) setelah menerima pesan. Efek ini adalah sebuah pengaruh yang dapat mengubah pengetahuan, perasaan, dan perilaku (Kognitif, afektif, dan konatif)

Lingkungan, adalah sebuah situasi yang dapat mempengaruhi terjadinya suatu komunikasi. Situasi Lingkungan terjadi karena adanya 4 faktor :
a) Lingkungan
Fisik(Letak Geografis dan Jarak)
b) Lingkungan Sosial Budaya (Adat istiadat, bahasa, budaya, status sosial)
$\begin{array}{lr}\text { c) Lingkungan } & \text { Psikologis } \\ \text { ( Pertimbangan } & \text { Kejiwaan }\end{array}$

seseorang ketika menerima pesan)

d) Dimensi Waktu (Musim, Pagi, Siang, dan Malam)

3. Model Komunikasi Bovee dan Thill

Bovee dan Thill dalam bukunya Bussiness Communication Today, menjelaskan bahwa proses komunikasi merupakan tahapan dari kegiatan. Terdapat 5 tahapan :

Pengirim memiliki sebuah Ide/Gagasan. Komunikasi diawali dengan adanya gagasan dari seorang pengirim, yang ingin disampaikan pada penerima pesan tersebut.

Ide Dirubah Menjadi Pesan. Ide bersifat abstrak dan tidak terstruktur, sehingga tidak dapat dibaca oleh oraglain. Maka dari itu, pengirim harus mengubah idenya tersebut menjadi sebuah pesan agar dapat dimengerti oleh orang lain. Perubahan ide menjadi suatu pesan dinamakan ENCODING.

Pemindahan Pesan. Setelah sebuah ide diubah menjadi pesan, maka pesan teresebut harus 
dipidahkan kepada penerima dengan berbagai bentuk komunikasi (Verbal, Nonverbal, Lisan atau Tertulis), dan media komunikasinya (Tatap muka, telepon, surat, laporan, dll)

Penerima menerima pesan. Penerima pesan menginterpretasikan pesan yang diterima.

Penerima pesan mengirimkan umpan balik. Umpan balik merupakan sebuah elemen perantai pesan. Sebagai pengirim pesan, kita harus mengevaluasi apa yang sebenarnya dipikirkan oleh penerima pesan. Apakah pesan kita efektif apa tidak. Jika pesan kita ternyata tidak efektif, maka pesan harus diulang.

Proses komunikasi dapat terjadi apabila ada interaksi antar manusia dan ada penyampaian pesan untuk mewujudkan motif komunikasi.

Tahapan proses komunikasi adalah sebagai berikut :

1. Penginterpretasian.

2. Penyandian.

3. Pengiriman.
4. Perjalanan.

5. Penerimaan.

6. Penyandian balik.

7. Penginterpretasian.

1. Penginterprestasian

Hal yang diinterpretasikan adalah motif komunikasi, terjadi dalam diri komunikator. Artinya, proses komunikasi tahap pertama bermula sejak motif komunikasi muncul hingga akal budi komunikator berhasil menginterpretasikan apa yang ia pikir dan rasakan ke dalam pesan (masih abstrak). Proses penerjemahan motif komunikasi ke dalam pesan disebut interpreting.

2. Penyandian

Tahap ini masih ada dalam komunikator dari pesan yang bersifat abstrak berhasil diwujudkan oleh akal budi manusia ke dalam lambang komunikasi. Tahap ini disebut encoding, akal budi manusia berfungsi sebagai encorder, alat penyandi: merubah pesan abstrak menjadi konkret. 
3. Pengiriman

Proses ini terjadi ketika komunikator melakukan tindakan komunikasi, mengirim lambang komunikasi dengan peralatan jasmaniah yang disebut transmitter, alat pengirim pesan.

\section{Perjalanan}

Tahapan ini terjadi antara komunikator dan komunikan, sejak pesan dikirim hingga pesan diterima oleh komunikan.

5. Penerimaan

Tahapan ini ditandai dengan diterimanya lambang komunikasi melalui peralatan jasmaniah komunikan.

\section{Penyandian Balik}

Tahap ini terjadi pada diri komunikan sejak lambang komunikasi diterima melalui peralatan yang berfungsi sebagai receiverhingga akal budinya berhasil menguraikannya (decoding).

7. Penginterpretasian

Tahap ini terjadi pada komunikan, sejak lambang komunikasi berhasil diurai kan dalam bentuk pesan.

C. Jenis-jenis komunikasi

Pada dasarnya komunikasi digunakan untuk menciptakan atau meningkatkan aktifitas hubungan antara manusia atau kelompok

Jenis komunikasi terdiri dari:

1. Komunikasi Verbal mencakup aspek-aspek berupa ;

a. Vocabulary (perbendaharaan kata-kata). Komunikasi tidak akan efektif bila pesan disampaikan dengan kata-kata yang tidak dimengerti, karena itu olah kata menjadi penting dalam berkomunikasi.

b. Racing (kecepatan). Komunikasi akan lebih efektif dan sukses bila kecepatan bicara dapat diatur dengan baik, tidak terlalu cepat atau terlalu lambat.

c. Intonasi suara: akan mempengaruhi arti pesan secara dramatik sehingga pesan akan 
menjadi lain artinya bila diucapkan dengan intonasi suara yang berbeda. Intonasi suara yang tidak proposional merupakan hambatan dalam berkomunikasi.

d. Humor. dapat meningkatkan kehidupan yang bahagia. Dugan (1989), memberikan catatan bahwa dengan tertawa dapat membantu menghilangkan stress dan nyeri. Tertawa mempunyai hubungan fisik dan psikis dan harus diingat bahwa humor adalah merupakan satusatunya selingan dalam berkomunikasi.

\section{e. Singkat dan jelas.} Komunikasi akan efektif bila disampaikan secara singkat dan jelas, langsung pada pokok permasalahannya sehingga lebih mudah dimengerti.

f. Timing (waktu yang tepat) adalah hal kritis yang perlu diperhatikan karena berkomunikasi akan berarti bila seseorang bersedia untuk berkomunikasi, artinya dapat menyediakan waktu untuk mendengar atau memperhatikan apa yang disampaikan.

2. Komunikasi Non Verbal

Komunikasi non verbal adalah penyampaian pesan tanpa katakata dan komunikasi non verbal memberikan arti pada komunikasi verbal.

Yang termasuk komunikasi non verbal :

\section{a. Ekspresi wajah}

Wajah merupakan sumber yang kaya dengan komunikasi, karena ekspresi wajah cerminan suasana emosi seseorang.

b. Kontak mata, merupakan sinyal alamiah untuk berkomunikasi. Dengan mengadakan kontak mata selama berinterakasi atau tanya jawab berarti orang tersebut terlibat dan menghargai lawan bicaranya dengan kemauan untuk memperhatikan bukan sekedar mendengarkan. Melalui kontak mata juga memberikan kesempatan pada orang lain untuk mengobservasi yang lainnya 
c. Sentuhan adalah bentuk mengetuk-ngetukan kaki atau komunikasi personal mengingat sentuhan lebih bersifat spontan dari pada komunikasi verbal. Beberapa pesan seperti perhatian yang sungguh-sungguh, dukungan mengerakkan tangan selama berbicara menunjukkan seseorang dalam keadaan stress bingung atau sebagai upaya untuk menghilangkan stress

emosional, kasih sayang atau simpati dapat dilakukan melalui sentuhan.

d. Postur tubuh dan gaya berjalan. Cara seseorang berjalan, duduk, berdiri dan bergerak memperlihatkan ekspresi dirinya. Postur tubuh dan gaya berjalan merefleksikan emosi, konsep diri, dan tingkat kesehatannya.

e. Sound (Suara). Rintihan, menarik nafas panjang, tangisan juga salah satu ungkapan perasaan dan pikiran seseorang yang dapat dijadikan komunikasi. Bila dikombinasikan dengan semua bentuk komunikasi non verbal lainnya sampai desis atau suara dapat menjadi pesan yang sangat jelas.

f. Gerak isyarat, adalah yang dapat mempertegas pembicaraan . Menggunakan isyarat sebagai bagian total dari komunikasi seperti

\section{Hambatan Komunikasi}

1. Hambatan Teknis

Keterbatasan fasilitas dan peralatan komunikasi. Dari sisi teknologi, semakin berkurang dengan adanya temuan baru dibidang kemajuan teknologi komunikasi dan informasi, sehingga saluran komunikasi dapat diandalkan dan efesien sebagai media komunikasi.Menurut dalam bukunya, 1976, Cruden dan Sherman Personel Management jenis hambatan teknis dari komunikasi :

a) Tidak adanya rencana atau prosedur kerja yang jelas

b) Kurangnya informasi atau penjelasan

c) Kurangnya ketrampilan 
membaca

d) Pemilihan media [saluran] yang kurang tepat.

2. Hambatan Semantik

Gangguan semantik menjadi hambatan dalam proses penyampaian pengertian atau secara secara efektif. Definisi semantik sebagai studi idea atas pengertian, yang diungkapkan lewat bahasa. Kata -kata membantu proses pertukaran timbal balik arti dan pengertian (komunikator dan komunikan), tetapi seringkali proses penafsirannya keliru. Tidak adanya hubungan antara Simbol (kata) dan apa yang disimbolkan (arti atau penafsiran), dapat mengakibatkan kata yang dipakai ditafsirkan sangat berbeda dari apa yang dimaksudkan sebenarnya. Untuk menghindari mis komunikasi semacam ini, seorang komunikator harus memilih kata-kata yang tepat sesuai dengan karakteristik komunikannya, dan melihat kemungkinan penafsiran terhadap kata-kata yang dipakainya.

3. Hambatan Manusiawi
Terjadi karena adanya faktor, emosi dan prasangka pribadi, persepsi, kecakapan atau ketidakcakapan, kemampuan atau ketidakmampuan alat-alat pancaindera seseorang, dll.

Menurut Cruden dan Sherman :

- Hambatan yang berasal dari perbedaan individual manusia.

Perbedaan persepsi, perbedaan umur, perbedaan keadaan emosi, ketrampilan

mendengarkan, perbedaan status, pencairan informasi, penyaringan informasi

- Hambatan yang ditimbulkan oleh iklim psikologis dalam organisasi.

Suasana iklim kerja dapat mempengaruhi sikap dan perilaku staf dan efektifitas komunikasi organisasi.

E. Mengatasi kendala Komunikasi dalam Organisasi

Beberapa solusi yang dapat ditawarkan dalam mengatasi kendalakendalavyang muncul dalam proses 
komunikasi organisasi antara lain :

\section{Hubungan Antar Persona}

Menciptakan hubungan intim yang dimiliki dengan orang-orang lain dalam tingkat pribadi, antar teman, sesama sebaya ataupun dengan atasan, biasanya disebut hubungan antar persona. Suatu anailisis khusus tentang hubungan antar pesona menyatakan bahwa kita akan berhasil menciptakan komunikasi dalam organisasi bila melakukan hal-hal berikut ini

1. Menjaga kontak pribadi yang akrab tanpa menumbuhkan perasaan bermusuhan

2. Menetapkan dan menegaskan identitas kita dalam hubungan dengan orang lain tanpa membesar-besarkan

ketidaksepakatan.

3. 3)Menyampaikan informasi kepada oranglain tanpa menimbulkan kebingunngan, kesalahpahaman, penyimpangan, atau perubahan lainnya yang disengaja
4. Terlibat dalam pemecahan masalah yang terbuka tanpa menimbulkan sikap mbertahan atau menghentikan proses

5. Membantu orang-orang lainnya untuk mengembangkan gaya hubungan persona dan antar pesona yang efektif

6. Ikut serta dalam interaksi social informal tanpa terlibat dalam muslihat

Hubungan antar pesona cenderung menjadi lebih baik bila kedua belah pihak melakukan hal-hal berikut yaitu menyampaikan perasaan secara langsung dan dengan cara yang hangat dan ekspresif, menyampaikan apa yang terjadi dalam lingkungan pribadi mereka melalui penyingkapan diri, menyampaikan pemahaman yang positif, hangat kepada satu sama lainnya dengan memberikan responsrespons yang relevan dan penuh pengertian, bersikap tulus kepada satu sama lain dengan menunjukan sikap menerima secara verbal 
maupun non verbal, selalu menyampaikan pandangan positif tanpa syarat terhadap satu sama lainnya dalam perbincangan yang tidak menghakimi dan ramah, berterus-terang mengapa menjadi sulit atau bahkan mustahil untuk sepakat satu sama lainnya dalam perbincangan yang tidak menghakimi, cermat, jujur, dan membangun.

2. Hubungan Posisional

Hubungan

posisional ditentukan dengan pendekatan struktur dan tugas-tugas fungsional anggota organisasi. Menurut Koontz dan O'Donnel (1968) untuk mengatasi kesalahan umum yang merintangi kinerja efektif dan efisien individu dalam organisasi yang disebabkan ketidaklancaran proses komunikasi di organisasi adalah:

a. Merencanakan penempatan / pengaturan jabatan secara benar

Sebagian dari kegagalan untuk merencanakan dengan benar lebih banyak terletak pada pengaturan orang-orang dari jabatan yang diberikan dari atasan sehingga pada akhirnya terjadi kegagalan dalam komunikasi horizontal dan vertikal yang ada dalam organisasi. Untuk dapat mencairkan kondisi tersebut ada baiknya melakukan rencana penempatan orang-orang yang ada di organisasi dengan berdasarkan kemampuan dan kesenioritasan yang diakui oleh individu-individu yang ada dalam organisasi

b. Berusaha menjernihkan hubungan

Kegagalan untuk menjernihkan hubungan organisasi menimbulkan kecemburuan, percekcokan, ketidakamanan, ketidakefisienan,dan pelepasan tanggung jawab lebih banyak dari kesalahan lainnya dalam pengorganisasian. Untuk itu perlu adanya individu yang dapat menjadi jembatan untuk mencairkan situasi kebekuan komunikasi horizontal dan vertikal antar sesama rekan dan antara bawahan - atasan..

3. Hubungan berurutan

Informasi disampaikan ke seluruh organisasi formal oleh suatu proses; dalamproses ini orang dipuncak hierarki mengirimkan pesan ; 
kepada orang kedua yangkemudian mengirimkannya lagi kepada orang ketiga. Reproduksi pesan orang pertama menjadi pesan orang kedua, dan reproduksi pesan orang kedua menjadi pesan orang ketiga. Tokoh kunci dalam sistem ini adalah pengulang pesan (relayor).

$$
\text { A.G. Smith }
$$

memperkenalkan empat fungsi dasar yang dilakukan seorangpengulang pesan, yaitu :menghubungkan, menyimpan, merentangkan dan mengendalikan. Para pengulang pesan adalah orang-orang perantara - penengah antara pengirim dan penerima. Mereka menghubungkan unit-unit sistem dengan menyelaraskan unit-unit tersebut satu sama lainnya19. Adakalanya pengulang pesan mengubah pesan yang dibawanya untuk tujuan menghasilkan keharmonisan antara unit-unit dalam sistem tersebut, namun mengubah pesan.

Menurut Koontz dan O'Donnel (1968) untuk mengatasi kesalahan umum yang merintangi kinerja efektif dan efisien individu dalam organisasi yang disebabkan ketidaklancaran proses komunikasi di organisasi adalah:

1) Merencanakan penempatan / pengaturan jabatan secara benar. Sebagian dari kegagalan untuk merencanakan dengan benar lebih banyak terletak pada pengaturan orang-orang dari jabatan yang diberikan dari atasan sehingga pada akhirnya terjadi kegagalan dalam komunikasi horizontal dan vertikal yang ada dalam organisasi. Untuk dapat mencairkan kondisi tersebut ada baiknya melakukan rencana penempatan orang-orang yang ada di organisasi dengan berdasarkan kemampuan dan kesenioritasan yang diakui oleh individu-individu yang ada dalam organisasi

2) Berusaha menjernihkan hubungan kegagalan untuk menjernihkan hubungan organisasi menimbulkan kecemburuan, percekcokan, ketidakamanan, ketidakefisienan, dan pelepasan tanggung jawab lebih banyak dari kesalahan lainnya dalam pengorganisasian. Untuk itu perlu 
adanya individu yang dapat menjadi jembatan untuk mencairkan situasi kebekuan komunikasi horizontal dan vertikal antar sesama rekan dan antara bawahan - atasan..

\section{Dalam mengatasi kendala} komunikasi dalam organisasi terdapat beberapa solusi untuk meminimalisir yaitu menciptakan hubungan intim yang dimiliki dengan orang-orang lain dalam tingkat pribadi, antar teman, sesama sebaya ataupun dengan atasan, biasanya disebut hubungan antar pesona. Kemudian perencanaan / pengaturan jabatan secara benar dan usaha untuk menjernihkan hubungan serta membuat reproduksi pesan orang pertama menjadi pesan orang kedua, dan reproduksi pesan orang kedua menjadi pesan orang ketiga. Tokoh kunci dalam sistem ini adalah pengulang pesan (relayor).

F. Komunikasi Menjadi Inti Kepemimpinan

Sebelum membahas pentingnya komunikasi dalam kepemimpinan, terlebih dahulu akan dipaparkan mengenai definisi kepemimpinan itu sendiri. Kepemimpinan adalah suatu proses mempengaruhi aktivitas kelompok dalam rangka perumusan dan pencapaian tujuan (Stokdil, 1948). Selain itu, menurut Robert Tennenbaun, Irving R. Wischler, dan Fred Massarik, definisi kepemimpinan menurut mereka adalah kepemimpinan sebagai pengaruh antar pribadi yang terjadi pada suatu keadaan dan diarahkan melalui proses komunikasi, kearah tercapainya sesuatu tujuan ataupun tujuan-tujuan yang sudah di tetapkan.

Dari pengertian kepemimpinan tersebut, dapat dilihat bahwa pada dasarnya komunikasi memiliki hubungan yang erat sekali dengan kepemimpinan, bahkan dapat dikatakan bahwa tidak ada kepemimpinan tanpa adanya komunikasi. Terlebih lagi, salah satu syarat untuk menjadi seorang pemimpin adalah memiliki kemampuan komunikasi yang baik. Hal tersebut dikarenakan kemampuan berkomunikasi akan sangat 
menentukan berhasil tidaknya seorang pemimpin dalam melaksanakan tugasnya. Setiap pemimpin (leader) memiliki pengikut (follower) guna merealisasikan gagasannya dalam rangka mencapai tujuan tertentu. Disinilah pentingnya kemampuan berkomunikasi sebagai seorang pemimpin, khususnya dalam mempengaruhi perilaku orang lain. Selain itu, jika dilihat dari pengertian kepemimpinan menurut Robert Tennenbaun, Irving R. Wischler, dan Fred Massarik yang mendefinisikan kepemimpinan sebagai pengaruh antar pribadi yang terjadi pada suatu keadaan dan diarahkan melalui proses komunikasi, kearah tercapainya sesuatu tujuan ataupun tujuan-tujuan yang sudah di tetapkan, maka semakin dapat dilihat bahwa sebenarnya komunikasi merupakan inti dari kepemimpinan karena pengaruh antar pribadi harus dilakukan melalui proses komunikasi. Tanpa adanya komunikasi, pengaruh antar pribadi dalam rangka mencapai tujuan tertentu tersebut tidak akan bisa dilakukan. Dengan kata lain, tanpa adanya komunikasi, tidak akan ada kepemimpinan.

Pada dasarnya, komunikasi tidak hanya penting bagi seorang pemimpin akan tetapi juga penting bagi para pengikut karena setiap tindakan, keputusan, dan arahan yang diambil atau diberikan oleh seorang pemimpin kepada pengikutnya, juga dilakukan dengan berkomunikasi. Jadi, pengikut juga harus memiliki kemampuan berkomunikasi guna lancarnya usaha dalam mencapai tujuan organisasi yang telah ditetapkan. Hanya saja, setiap pemimpin dituntut untuk lebih efektif dan efisien dalam berkomunikasi, mengingat krusialnya implikasi dari setiap tindakan, keputusan dan perilaku seorang pemimpin sehingga akhirnya muncul istilah komunikasi kepemimpinan atau leadership communication. Komunikasi kepemimpinan itu sendiri adalah sebuah model komunikasi bagi para pemimpin, di mana bentuk komunikasi disesuaikan dengan posisinya sebagai pemimpin. Ini berarti, ada spesifikasi khusus dari elemen bahasa yang digunakannya. 
Oleh karena itu, pemimpin yang efektif harus memahami pentingnya komunikasi yang baik karena masalah dalam komunikasi (miskomunikasi) dapat menyebabkan 'bottleneck' di dalam suatu organisasi.

Kepemimpinan yang berhasil mempengaruhi orang lain sangat ditentukan oleh keterampilan dan kemampuan menjalankan fungi komunikasi secara baik karenanya komunikasi yang baik dan menjadi efektif akan ditentukan pula oleh kepercayaan dan keyakinan seorang pemimpin dalam memimpin untuk mempengaruhi bawahan.

Keyakinan dan kepercayaan hanya dapat terbentuk apabila pemimpin menyadari suatu lingkungan yang harmonis antara pimpinan dengan para bawahannya yang dapat benar-benar berkomunikasi dengan baik yang sejalan dengan makna fungsi komunikasi. Pertama ia menyadari untuk melaksanakan pengungkapan emosional (fungsi) dengan sikap dan perilaku yang dapat menimbulkan kesan yang menarik mereka dari tindakannya dari pada kata-kata.

Kedua pesan yang disampaikan mengenai fakta dan informasi (fungsi) yang dapat dipertanggung jawabkan. Ketiga mampu memberi daya dorong agar termotivasi kearah (fungsi) yang memenuhi kepentingan semua pihak. Keempat mampu menjalankan kendali (fungsi) untuk dapat menerima dan mendengarkan konskuensi berkomunikasi serta membuat langkah lanjutan dalam tindakan.

Disatu sisi kita dapat memahami makna fungsi komunikasi dan disisi lain diperlukan kemampuan dan keterampilan untuk mendalami aktualisasi kedalam proses komunikasi karena kita harus meyakini bahwa tindakan lebih membekas daripada kata-kata, jadi dapat saja pemimpin melakukan komunikasi, tetapi ia tidak mengambil tindakan, itu berarti tak ada seorangpun akan mempercayai komunikasi tersebut, akibatnya dapat menimbulkan sindrom dalam bentuk 
gejala pura-pura atau bentuk mental yang suka menunda-nunda.

Oleh karena itu, pengkodean (proses) mengubah suatu pesan komunikasi menjadi bentuk simbol artinya apa yang dikomunikasikan, saluran (proses) artinya mediun lewat mana sesuatu pesan komunikasi berjalan, pendekodean (proses) artinya penerjemahan ulang pesan komunikasi seorang pengirim, gelung umpan balik (proses) artinya tautan akhir dalam proses komunikasi mengembalikan pesan ke dalam sistem guna memeriksa kesalahpahaman.

Dengan demikian untuk menjadikan komunikasi yang efektif menuntut pengasahan secara terus menerus oleh pemimpin yang menyadari bahwa kepemimpinan akan berhasil bila secara sungguh-sungguh memahami fungsi komunikasi disatu sisi dan disisi lain melaksanakan proses komunikasi, sehingga waktu hidup kita sebagian besar dipergunakan dalam berpikir untuk menulis, membaca, berbicara dan mendengarkan dalam kerangka hubungan individu, kelompok dan organisasi.

Komunikasi merupakan seni atau cara untuk menyampaikan sesuatu agar orang lain dapat memahami kita. Apalagi syarat seorang pemimpin selain ia harus berilmu, berwawasan luas ke depan, ikhlas, tekun, berani, jujur, sehat jasmani dan rohani, ia juga harus memiliki kemampuan berkomunikasi yang baik. Kemampuan berkomunikasi akan sangat menentukan berhasil tidaknya seorang pemimpin dalam melaksanakan tugasnya. Setiap pemimpin memiliki pengikut guna merealisasikan gagasannya dalam rangka mencapai tujuan tertentu. Disinilah pentingnya kemampuan berkomunikasi bagi seorang pemimpin, khususnya dalam usaha untuk mempengaruhi perilaku orang lain.

Komunikasi memiliki hubungan yang sangat erat dengan kepemimpinan, bahkan dapat dikatakan bahwa tiada kepemimpinan tanpa komunikasi. Dalam kehidupan 
seorang pemimpin, keberhasilannya ditentukan dari cara bagaimana dia dapat berkomunikasi dengan anak buahnya atau pekerjanya. Dan keberhasilannya dalam berkomunikasi itu dapat menjadi indikator bagi keberhasilan /kemajuan perusahaan yang dipimpinnya. Lingkaran pusat kepemimpinan adalah komunikasi. Komunikasi merupakan seni atau cara untuk menyampaikan sesuatu agar orang lain dapat memahami kita. Apalagi syarat seorang pemimpin selain ia harus berilmu, berwawasan luas ke depan, ikhlas, tekun, berani, jujur, sehat jasmani dan rohani, ia juga harus memiliki kemampuan berkomunikasi yang baik. Kemampuan berkomunikasi akan sangat menentukan berhasil tidaknya seorang pemimpin dalam melaksanakan tugasnya. Setiap pemimpin memiliki pengikut guna merealisasikan gagasannya dalam rangka mencapai tujuan tertentu. Disinilah pentingnya kemampuan berkomunikasi bagi seorang pemimpin, khususnya dalam usaha untuk mempengaruhi perilaku orang lain.

Seperti yang dilakukan oleh orang lain, setiap tindakan, keputusan, dan arahan yang diambil atau diberikan oleh seorang pemimpin, juga dilakukan dengan berkomunikasi. Hanya saja, setiap pemimpin dituntut untuk lebih efektif dan efisien dalam berkomunikasi, mengingat krusialnya implikasi dari setiap tindakan, keputusan dan perilaku seorang pemimpin.

Komunikasi kepemimpinan atau leadership communication, adalah sebuah model komunikasi bagi para pemimpin, di mana bentuk komunikasi disesuaikan dengan posisinya sebagai pemimpin. Ini berarti, ada spesifikasi khusus dari elemen bahasa yang digunakannya.

Jadi, pemimpin yang efektif harus memahami pentingnya komunikasi yang baik. Komunikasi dapat didefenisikan sebagai penyampaian informasi antara dua orang atau lebih. Komunikasi merupakan suatu proses yang vital dalam organisasi karena komunikasi diperlukan untuk mencapai efektifitas dalam kepemimpinan, perencanaan, 
pengendalian, koordinasi, latihan, manejemen konflik serta prosesproses organisasi lainnya. Lalu bagaimana mungkin komunikasi bisa berjalan dengan baik jika seorang pemimpin tidak memberikan kenyamanan malahan yang ada adalah ketakutan bagi bawahannya dalam menyampaikan informasi kepadanya? Jika komunikasi berjalan dengan baik, dua orang tidak lagi menjadi objek yang mati satu sama lainnya, melainkan telah membukakan celah bagi satu sama lain untuk menjadi pribadi dan dua pribadi yang saling mengungkapkan penghargaannya.

Komunikasi merupakan sebuah komponen penting dalam suatu kepemimpinan. Seorang pemimpin yang baik salah satunya dinilai dari caranya berkomunikasi. Oleh karena itu, penting bagi pemimpin untuk memahami guideline mengenai cara yang efektif dalam berkomunikasi. Dengan demikian seorang pemimpin harus bisa dipercaya dan harus mampu mengkomunikasikan visi perusahaan kepada para karyawannya. Beberapa prinsip kepemimpinan yang harus dimiliki antara lain:

1. Memahami karakter para pengikutnya. Gaya kepemimpinan yang diterapkan ada yang bersifat umum dan spesifik bergantung pada karakter pribadi masing-masing karyawan. Misalnya gaya memimpin harus disesuaikan dengan perbedaan karyawan baru dan karyawan senior; karyawan yang bermotivasi rendah dan yang bermotivasi tinggi. Intinya seorang pemimpin harus memahami kebutuhan, kepentingan, emosi, dan motivasi para karyawannya dengan bijak.

2. Mengenali dan memahami karakter diri sang pemimpin sendiri. termasuk harus tahu apa yang diketahui dan diperbuatnya. Pemimpin harus memiliki percaya diri. Kalau tidak maka para karyawan kurang menghargai sang pemimpin. Karena itu pemimpin yang dihormati bukan karena posisinya tetapi lebih pada karakternya.

3. Pemimpin harus memiliki 
kemampuan efektif dengan para karyawan khususnya nonverbal. Isi pesan harus disampaikan secara lugas dan sederhana. Selain itu umpan balik sangat strategis dilakukan untuk memelajari setiap pesan dalam upaya memperbaiki kinerja perusahaan. Seorang pemimpin harus mampu menjadi pendengar yang baik.

\section{DISKUSI}

Komunikasi? Apa itu?

A. Komunikasi adalah kegiatan perilaku atau kegiatan penyampaian pesan atau informasi tentang pikiran atau perasaan.

B. Komunikasi tidak terbatas pada kata-kata yang terucap belaka, melainkan bentuk dari apa saja interaksi, senyuman, anggukan kepala yang membenarkan hati, sikap badan, ungkapan minat, sikap dan perasaan yang sama.

C. Komunikasi tidak terbatas pada kata-kata yang terucap belaka, melainkan bentuk dari apa saja interaksi, senyuman, anggukan kepala yang membenarkan hati, sikap badan, ungkapan minat, sikap dan perasaan yang sama.

\section{F. Kesimpulan}

Beberapa kesimpulan yang dapat disampaikan dalam tulisan ini antara lain pentingnya seorang pemimpin dan bawahan untuk dapat membuka komunikasi secara efektif dan efisien sehingga roda organisasi dapat berjalan dengan lancar dalam mencapai tujuan ( goal ) yang telah ditentukan. Kemudian seluruh individu yang tergabung dalam sistem organisasi hendaknya menyadari perlunya ketanggapsegeraan untuk meminimalisir hambatan komunikasi yang terjadi dengan melakukan beberapa pendekatan / solusi yang ditawarkan yaitu menciptakan hubungan yang lebih baik. Maka itu dikatakan bahwa inti dari kepemimpinan adalah adanya komunikasi yang berjalan dengan baik.

\section{F. REFERENSI}


[1] PUTRA, Arie Setya; FEBRIANI, Ochi Marshella, Knowledge Management Online Aplication in PDAM Lampung Province. In: Prosiding International Conference On Information Technology and Business (ICITB).2018.P.181-187.

[2] FEBRIANI, Ochi Marshella; PUTRA,Arie Setya. Sistem Informasi Monitoring Inventori Barang Pada Balai Riset Standardisasi Industri Bandar Lampung. Jurnal Informatika,2014, 13:1:90-98

[3] PUTRA,A.S.(2018.July9). 2018 Artikel Struktur Data, Audit dan Jaringan Komputer, Retr1ievedfrom osf.io/3uq8w.

[4] Hariyanto, Bambang. 2000. Struktur Data. Bandung: CV. Informatika. Modul Dasar StrukturData"BSI".

[5] Desphande P.S., O.G. Kakde (2004).C dan Data Structures. Charles River Media, Inc.Massachusetts. 